DOI https://doi.org/10.36059/978-966-397-155-1/44-61

\title{
CHARACTERISTICS OF TRAUMATISM OF THE POPULATION OF TRANSCARPATHIAN REGION
}

\section{Brych V. V.}

\section{INTRODUCTION}

The health of the population always occupies the most important part in the welfare system of the state. Recently, chronic noncommunicable diseases have been increasingly recognized as a major contributor to public health. However, less attention has been paid to injuries, which also have a significant impact on health, morbidity, disability and mortality.

Injuries, whether intentional or unintentional, are the third leading cause of death in the World Health Organization (WHO) European Region and pose a threat to economic and social development ${ }^{1}$. In general, injuries are a major cause of death of people aged 5-49 years, and the death rate from injury is 2,4 times higher in low- and middle-income countries compared with high-income countries. Injuries also exacerbate disease burden, measured in disability-adjusted life years (DALY) or years of healthy living, lost as a result of premature death or disability. In 2015, the injury-related burden that caused the loss of 28 million DALY represented $9.4 \%$ of all DALY lost ${ }^{2}$.

Traumatism is a combination of injuries that occur over a certain period of time in a certain territory among a certain population group. The following are considered the main types of injury in Ukraine: traffic road, occupational, domestic, sports and street injuries.

The incidence of the category of diseases «Injury, poisoning and certain other consequences of external causes (S00-T98)» in Ukraine in recent years has been more stable, ranging from 4023 to 100 thousand

\footnotetext{
${ }^{1}$ Sethi D, Mitis F, Racioppi F. (2010). Preventing injuries in Europe: from international collaboration to local implementation. Copenhagen: WHO Regional Office for Europe. Retrieved from: http://www.euro.who.int/en/publications/ abstracts/preventing-injuries-ineurope-from-international-collaboration-to-localimplementation.

${ }^{2}$ Aldridge E, Sethi D. Yon Y. (2017). Injuries: a call for public health action in Europe. Copenhagen: WHO Regional Office for Europe. Retrieved from: http://www.euro.who.int/ data/assets/pdf_file/0018/348102/WH08_IJ_complete-web-version.pdf?ua=1 
people in $2014^{3}$ to 4010 in 2017 , while in 2000 and 2010 this figure was 4749 and 4853 per 100 thousand population respectively ${ }^{4}$. Despite the fact that the share of the above category in the structure of the general morbidity of the population of Ukraine is small (6-6,5\%), it remains one of the main causes of disability.

Occupational traumatism occupies a special place. In Ukraine the situation in the field of labor protection has remained tense in recent years. The current Occupational Health and Safety Management System has proved to be insufficient in the current conditions. As a consequence, the level of injuries in the workplace remains relatively high ${ }^{5}$.

Medical and social impact of injury is significant not only because of its spread and high mortality rate, but also because injuries cause significant economic losses to industries, leading to increased costs of healthcare, social benefits and improving quality of life for people with disabilities.

Special attention is given to the westernmost region of Ukraine, the Transcarpathian region, which is characterized by certain features: the predominance of rural population $(63 \%)$, borderline placement (it borders with 4 other countries), a large number of villages with the status of mountain settlements, recurrent natural disasters such as floods, massive migration to other regions of Ukraine and abroad, and so on. This can lead to increased traumatism and therefore require taking special measures for injury prevention and medical care, including rehabilitation.

Trauma management has 2 main components: trauma prevention and trauma care, including rehabilitation. To ensure the full implementation of these components in the regions, it is necessary to understand the main trends in the epidemiology of trauma in the target area.

It should be emphasized that the best conditions for collecting information on all injuries requiring outpatient medical intervention, observation and/or hospital treatment, as well as for objective assessment

3 Derzhavna sluzhba statystyky Ukrainy (2017) Zaklady okhorony zdorov'ja ta zakhvorjuvanistj naselennja Ukrajiny u 2016 roci [Healthcare institutions and the incidence of the population of Ukraine in 2016], Kyiv. Retrieved from: http://www.ukrstat.gov.ua/ druk/publicat/kat_u/2016/bl/06/bl_zoz_15xl.zip

4 Derzhavna sluzhba statystyky Ukrainy (2018) Zaklady okhorony zdorov'ja ta zakhvorjuvanistj naselennja Ukrajiny u 2017 roci [Healthcare institutions and the incidence of the population of Ukraine in 2017], Kyiv. Retrieved from: http://www.ukrstat.gov.ua/ druk/publicat/kat_u/2018/zb/06/zb_zoz_17.pdf

5 Dmytrjuk S. P., Ghodjajev S. Gh. (2017). Osnovni prychyny ta metody analizu pokaznykiv vyrobnychogho travmatyzmu [Principal reasons and methods of analysis of indexes of production traumatism of]. Budivnyctvo, materialoznavstvo, mashynobuduvannja. Zb. nauk. pracj. [Construction, materials science, mechanical engineering], vol. 101, pp.94-99. 
and identification of the most serious cases with serious consequences, can only be ensured by a network of health care institutions ${ }^{6}$. In order to plan injury prevention measures in a particular region of Ukraine, the Transcarpathian region, it was decided to analyze the dynamics and the state of the spread of different types of injuries in the region. Therefore, we have analyzed statistical reference «Network of institutions and key indicators of the health system in the Transcarpathian region» for 2014-2018.

\section{Injury and its structure in the Transcarpathian region in 2014-2018}

The current state of health care in Ukraine is extremely unsatisfactory. According to WHO, Ukraine has entered the so-called «red zone». In 2017 noncommunicable diseases killed 605,000 people in Ukraine, which is approximately $90 \%$ of all deaths ${ }^{7}$. Of course, these nationwide tendencies are observed in all regions of Ukraine; however, it should be noted that the Transcarpathian region is characterized by its peculiarities. They are related to geographical, socio-economic and cultural features that have formed historically.

Despite the poor state of health of the population, there has been a trend in Ukraine and the Transcarpathian region in particular of overall morbidity reduction over the last three years (2016-2018). Thus, in 2016 the levels of general morbidity increased to 64375 per 100 thousand population in Ukraine and 61084.6 per 100 thousand in the Transcarpathian region compared to 2014 (62759,0 and 60007,7 respectively) and 2015 (62775,0 and 60615,1 respectively); however, in 2017 and 2018 in the Transcarpathian region they reduced to 58729,9 and 57469,3 per 100 thousand population respectively, while in Ukraine they reduced to 62895 per 100 thousand population in 2017 (Fig. 1).

Recently, the most widespread chronic noncommunicable diseases and socially dangerous infectious diseases have received increasing attention in all regions of Ukraine. However, injury as an important component of health problems and disability in population remains neglected, though it can significantly affect the working age population.

In order to study the injury situation, we have analyzed the level of total injuries in the Transcarpathian region and their structure (Table 1).

6 Lazebnyk Ju. O. (2018). Proghramno-metodologhichni zasady udoskonalennja nacionaljnoji systemy sposterezhennja zi statystyky travmatyzmu [Program-methodological Principles of Improvement of the National System of Statistical Observation of Traumatism]. Statistics of the Ukraine, no. 3, pp. 49-58.

${ }^{7}$ Barannyk L. B. (2019) Zdorov'ja naselennja jak indykator rozvytku socialjnogho kapitalu v Ukrajini [Public health as an indicator of the social capital development in Ukraine]. Scientific Notes of Ostroh Academy National University, «Economics» series, no. 12, pp. 64-69. Retrieved from: http://nbuv.gov.ua/UJRN/Nznuoa_2019_12_12. 


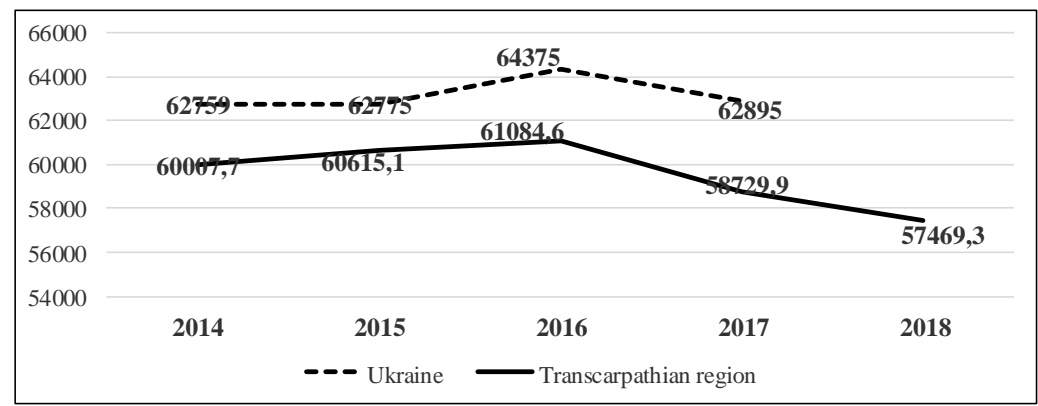

Fig. 1. Morbidity rates in Ukraine and Transcarpathian region in 2014-2018 (per 100000 population)

Table 1

Injury rate of the entire population of the Transcarpathian region in 2014-2018 (per 100 thousand population)

\begin{tabular}{|c|c|c|c|c|c|}
\hline \multirow{2}{*}{ Type of injury } & \multicolumn{5}{|c|}{ Years } \\
\cline { 2 - 6 } & $\mathbf{2 0 1 4}$ & $\mathbf{2 0 1 5}$ & $\mathbf{2 0 1 6}$ & $\mathbf{2 0 1 7}$ & $\mathbf{2 0 1 8}$ \\
\hline General & 3841 & 3771 & 3881 & 3591 & 3553 \\
\hline Domestic & 3389 & 3295 & 3409 & 3187 & 3196 \\
\hline Street traumas & 331 & 346 & 344 & 338 & 291 \\
\hline Traffic road injuries & 40 & 50 & 57 & 44 & 41 \\
\hline Sports injuries & 13 & 18 & 11 & 13 & 12 \\
\hline Other & 68 & 62 & 60 & 9 & 13 \\
\hline
\end{tabular}

The overall injury rate of the entire population in the Transcarpathian region over the 5 years since 2014 (3841 per 100 thousand population) has decreased by 7,5\%, although it increased in 2016 (3553 per 100 thousand population) (Fig. 2).

Thus, in 2014, the rate of general injury was 3841 per 100 thousand population, in 2015 it decreased by $1,8 \%$ to 3771 per 100 thousand population, and in 2016 it increased by 1\% (3881 per 100 thousand population). In 2017, there was a more significant reduction in the overall injury in the Transcarpathian region by $7,5 \%$ to the level of 3591 per 100 thousand population, while in 2018 it decreased by only 1\% (3553 per 100 thousand population). Also, general traumatism structure for the period of 2014-2018 was studied, the results of the study are presented in Figure 3. This period was characterized by an increase in the share of domestic injuries, a decrease in street and minor fluctuations in road, sports and industrial injuries. 


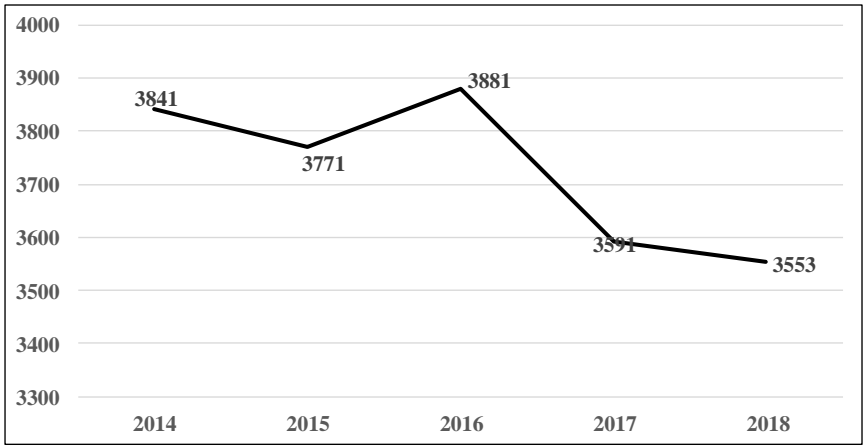

Fig. 2. Dynamics of the rates of general traumatism in the Transcarpathian region in 2014-2018 (per 100 thousand population)

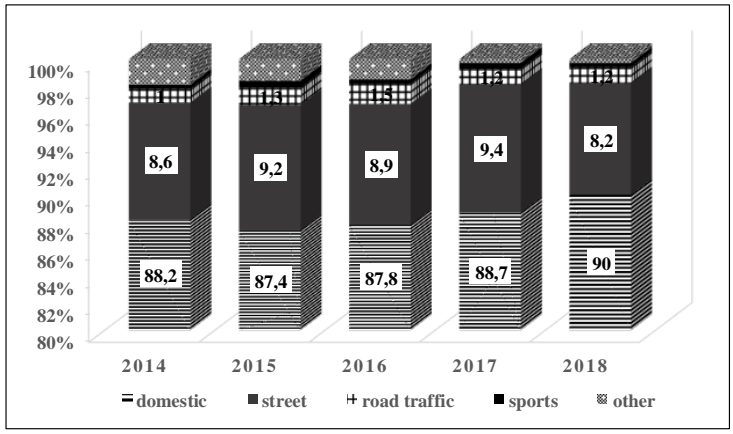

Fig. 3. Structure of traumatism in the Transcarpathian region in 2014-2018 (\%)

At the same time, the largest share in the structure of general traumatism in all years belonged to domestic injury (87.4-90\%) (Fig. 3). This type of injury ranked first among all trauma of the population. The structure of domestic injuries includes wounds, burns, bruises, dislocations, etc. Life in modern conditions is characterized by the excessive amount of various equipment and vehicles in production and households. As a result, people are constantly exposed to dangerous factors during a particular activity. Domestic traumatism combines injuries that occur at home (in the apartment, in the yard). Many injuries occur during quarrels and fights under the influence of alcohol. 
In 2014, domestic injuries in the Transcarpathian region accounted for $88.2 \%$ of the total injury and amounted to 3389 per 100000 population. In 2015, its level increased by 2,6\% to 3295 per 100 thousand population. This represented $87,4 \%$ of the total traumatism in the region. In the following years, there was a gradual decrease in the level of domestic injuries from 3409 per 100000 population in 2016 to 3196 per 100000 population in 2018 (Fig. 4).

At the same time, the share of domestic injuries in the total structure increased from $87.8 \%$ in 2016 to $88,7 \%$ and $90 \%$ in 2017 and 2018, respectively (Fig. 3).

In order to better understand the rates of injuries in Transcarpathian region, it should be noted that the region is characterized by certain geographical peculiarities. Geographically the region can be divided into three landscape zones. The first zone includes 2 mountainous districts (Mizhhiria and Rakhiv), the second - 2 plain areas (Vynohradiv and Berehove), and the third 9 mountain-plain areas (Uzhhorod, Mukachevo, Perechyn, Velykyi Bereznyi, Volovets, Tiachiv and Irshava).

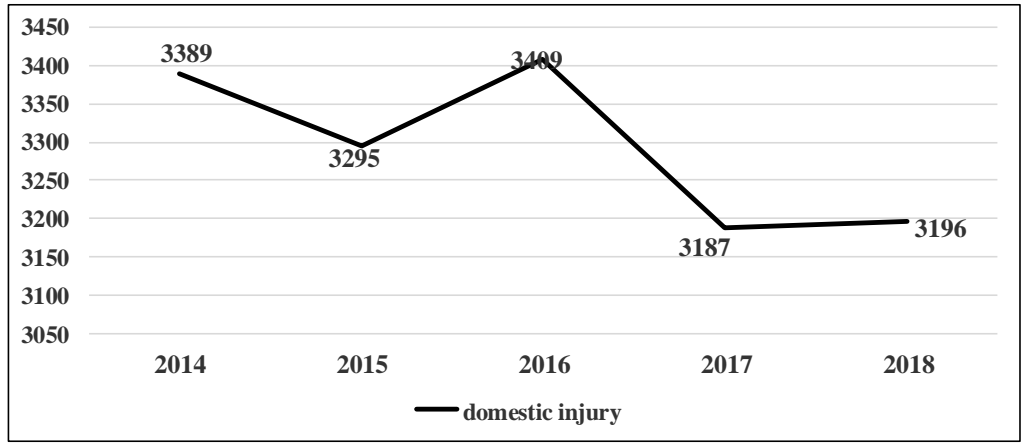

Fig. 4. Dynamics of domestic injury rates in the Transcarpathian region in 2014-2018 (per 100 thousand population)

Particularly noteworthy is Rakhiv district, where the level of domestic injuries, with a tendency to decline over the years of the study, exceeded 5000 per 100 thousand population (5694 in 2014; 5248 in 2015; 5359 in 2016; 5294 in 2017; 5044 in 2018), and also exceeded the national average by 1,5 times. It should be noted that this district is characterized by a significant proportion of the mountain population $(81,9 \%)$. At the same time, such high rates of domestic injuries were not found in other mountainous districts. The lowest level of domestic injuries in all years of the study (2014-2018) was recorded in Uzhgorod district. In five years, it has seen a 
2,2-fold decrease: from 1847 to 825 per 100000 population. This difference is connected with the peculiarities of the registration, since the trauma in Uzhhorod, the regional center is recorded separately and in all years exceeds the regional rate of domestic trauma by 1,3 times.

In order to prevent domestic injuries in the region, measures should be taken to improve living conditions and expand public services to the population, organize leisure and various large-scale cultural and recreational events efficiently, and carry out purposeful work on creating safe domestic environment. All these activities should be carried out with public involvement.

The study of the traumatism in the region has shown that street injury was the next; in 2014-2018 it occupied the second place in the structure of traumatism among the population of the Transcarpathian region $(8,2-9,2 \%)$ (Fig. 3). In 2014, street injuries were reported at the level of 331 per 100 thousand population and accounted for $8,6 \%$ of the total injuries, in 2015 the rate was 346 per 100 thousand population $(9,2 \%)$, in $2016-344$ per 10 thousand population $(8.9 \%)$, in $2017-338$ per 100 thousand population $(9,4 \%)$, and in 2018-291 per 100 thousand population (8,2\%) (Fig. 3, Fig. 5).

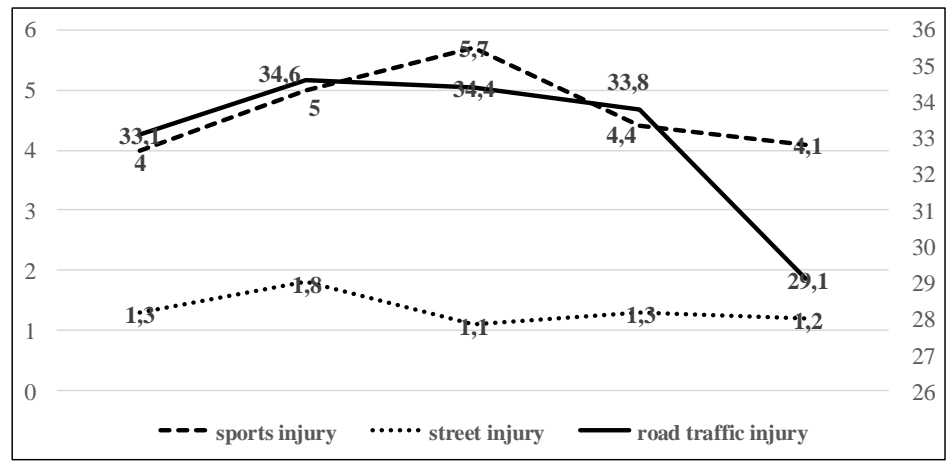

Fig. 5. Dynamics of the rates of street, road traffic and sports injuries in the Transcarpathian region in 2014-2018 (per 10 thousand population)

With a view to preventing street injuries, the authorities raise questions about the rational planning and maintenance of streets and squares with their subsequent proper care and proper lighting. Equally important are the fences of homes under construction or repair, safety of children's leisure, information campaigns for the public (print, radio, television, films, lectures, reports, etc.) on the street safety rules, fight against the use of psychoactive substances, as street injuries often occur to intoxicated persons. 
Road traffic injuries also cause significant damage to public health. Road accidents are caused by different types of vehicles in their movement (traffic) in cases not related to the production activities of the victims, regardless of the victim's presence in the vehicle (driver, passenger) or outside it (pedestrian) at the moment of the accident. A vehicle is any machine used to transport cargo, objects or people (car, motorcycle, bicycle, airplane, steamer, trolleybus, tram, railroad, horse-drawn transport, etc.). Injury in road accidents is caused by a large number of reasons.

The severity of this type of injury is greatly influenced by factors such as the vehicle's speed, the driver's use of psychoactive substances, condition and category of the road, type of settlement, weather conditions, as well as time of the year and time of the day. In Ukraine, the largest number of road accidents is recorded in late summer and autumn months. This is explained by the fact that with relatively high traffic intensity (especially during harvesting campaigns), the weather and climatic conditions, the operational state of the roads (vehicles bringing dirt on the road from unpaved exits, wetting caused by rainfall at the road sides, especially soft shoulders), light and visibility on the road (shortening of daylight hours, fog, rain) become worse. In winter, the accident rate continues to be high, which is caused by poor visibility due to the short duration of the daylight hours, cloudy weather and ice formation on the road surface.

Therefore, road traffic injuries occupy the third place in the structure of general traumatism of the population in the Transcarpathian region (Fig. 3). Within five years its share ranged from $1 \%$ to $1,5 \%$. Since 2014 , there has been an increase in the level of traffic injuries from 40 to 50 and 57 per 100 thousand population in 2015 and 2016 over 3 subsequent years. Instead, in 2017, the number of road injuries in the Transcarpathian region decreased sharply by $29,5 \%$ to 44 per 100 thousand people. And in 2018, the level of this type of injury decreased by another $7 \%$, returned almost to the figure of 2014 and amounted to 41 per 100 thousand population. At the same time, road accidents accounted for $1,2 \%$ of the total injuries in the Transcarpathian region in 2017 and 2018.

It should be noted that the highest level of traffic injuries is characteristic of Mizhhiria district, where $100 \%$ of the villages the status of mountain settlements, and the roadways do not have the status of roads of international importance. Thus, if in 2014 traffic injury rate in the district exceeded the regional by 2,5 times (100 against 40 per 100 thousand population), in 2019 it exceeded the regional rate by 5.3 times ( 219 against 41 per 100 thousand people). The lowest rate of traffic injuries was registered in Mukachevo district. 
In order to prevent road traffic injuries within the framework of public health protection, the «National Action Plan on the Prevention of Noncommunicable Diseases for Achieving Global Sustainable Development Goals» dated 26.07.2018 No. 530-p was adopted by the Cabinet of Ministers of Ukraine ${ }^{8}$. It provides for the preparation and dissemination of information materials to drivers of vehicles and students of driving schools about the effects of driving under the influence of alcohol and drugs; ensuring that traffic safety training materials are included in the training programs for doctors and nurses; involvement of police officers at the local level in training on key behavioral factors; developing and day-to-day involvement of primary care workers; carrying out information campaigns about use of child car seats, developing regulations to increase responsibility for driving in the state of alcohol / drug / toxic substance intoxication.

The above regulatory document also provides for monitoring road safety, which includes:

1) ensuring the establishment of a national road traffic surveillance system, the registration of road accidents, and road traffic deaths and injuries;

2) ensuring the collection of objective and reliable data on gross violations of road safety (speeding, non-use / misuse of seat belts, child seats, helmets, influence of factors distracting from driving);

3 ) ensure the revision of indicators of monitoring road safety violations at the national and regional level for the current assessment of road safety.

The next stage of the study was the analysis of sports injuries. They occur to people involved in sports during exercise or sports competitions. Sports injuries rarely result in death, but they have a significant impact on athletes' health, both immediately after the injury and later. Among all diseases of athletes, almost half account for injuries and traumatic diseases of the musculoskeletal system. The greatest number of sports traumas are due to the influence of physical (mechanical and temperature) factors, and the most common are mechanical ones.

The analysis of the structure of general traumatism in the Transcarpathian region shows that sports traumatism is hardly characteristic of the region, and its share in the structure of general traumatism in 2014,

\footnotetext{
${ }^{8}$ Pro zatverdzhennja Nacionaljnogho planu zakhodiv shhodo neinfekcijnykh zakhvorjuvanj dlja dosjaghnennja ghlobaljnykh cilej stalogho rozvytku [National Action Plan on the Prevention of Noncommunicable Diseases for Achieving Global Sustainable Development Goals]: Rozporjadzhennja Kabinetu Ministriv Ukrajiny [Cabinet of Ministers of Ukraine] 2018, No. 530-p. Retrieved from: https://www.kmu.gov.ua/ua/npas/pro-zatverdzhennyanacionalnogo-planu-zahodiv-shchodo-neinfekcijnih-zahvoryuvan-dlya-dosyagnennyaglobalnih-cilej-stalogo-rozvitku
} 
2016 and 2018 amounted to $0,3 \%$, in 2015 it increased slightly and amounted to $0,5 \%$, and in 2014 to $0,4 \%$.

The analysis of the sports injury has revealed that in 2015 its rate (13 per 100 thousand population) increased by 38,5\% compared to 2014 (18 per 100 thousand population). At the same time, in 2016 it decreased by $39 \%$ up to 11 per 100 thousand population. In 2016 and 2017, the sports injury rates were set as 13 and 12 per 100 thousand residents of the Transcarpathian region.

Particular attention should be paid to occupational injuries. According to the State Labor Service of Ukraine, the absolute values of occupational injuries in Ukraine have decreased by $35 \%$ in the last five-year period of 2014-2018 (6318 cases in 2014, 4126 in 2018). According to the same data, the absolute value of industrial injuries in the Transcarpathian region increased by $16 \%$ (from 44 cases in 2014 to 51 in 2018) ${ }^{9}$. The Transcarpathian region together with some other regions of Ukraine (Chernivtsi, Ternopil, Mykolaiv, Kirovohrad) is characterized by the lowest rate of occupational injuries, with $0,84 \%$ of accidents in $2014-2018^{10}$.

Occupational injury prevention has always been an important part of the measures taken by the government to combat traumatism. Creation of proper working conditions at every workplace, safety and health protection are urgent problems in Ukraine, as there is high morbidity and mortality rate among people of working age, increased levels of occupational and domestic injuries, including ones with lethal consequences. Therefore, in order to prevent occupational injury and to increase the level of production safety, employers, in the first place, should take the following measures: ensure that the safety management system is in place at the enterprise; identify the probability of accidents at work in time and warn employees about the possibility of such situations; eliminate the causes leading to accidents; provide training and assessment of knowledge on the safety of workers, including workers engaged in high-risk work; ensure that employees comply with the requirements of industrial and labor discipline; monitor employees' compliance with the requirements of legislative and regulatory acts on labor protection.

\footnotetext{
${ }^{9}$ State Service of Ukraine on Labor (2019) Statystychni dani vyrobnychogho travmatyzmu z pochatku roku [Statistical data occupational injuries YTD]. Retrieved from: http://dsp.gov.ua/ statystychni-dani-vyrobnychoho-travma-2/

${ }^{10}$ Mitina NB., Babenko O.Ju., Vorobjova L.O., Malynovsjka N.V. (2018) Doslidzhennja stanu travmatyzmu ta rivnja profesijnoji zakhvorjuvanosti na promyslovykh ob'jektakh Ukrajiny [Study of the state of traumatic and professional disease level on industrial objects of Ukraine]. Budivnyctvo, materialoznavstvo, mashynobuduvannja. Zb. nauk. pracj. [Construction, materials science, mechanical engineering], vol. 105, pp.139-147.
} 
The level of injury among children and young people is important in predicting the health of the population, but statistics on its spread in these age groups have not been found. As this category of the population is the future of the country, special attention is paid to the prevention of injuries. This policy is regulated by legislation, in particular the order of the Ministry of Education and Science of Ukraine No. 659 of May 16, 2019 On Approval of the «Regulation on the Procedure of Investigation of Accidents that Occurred with the Students During the Educational Process» ${ }^{11}$. In order to prevent injuries in schools, measures are being taken in accordance with the aforementioned document, which establishes a uniform procedure for investigating and keeping records of accidents that have occurred with pupils, students, cadets, trainees, interns, graduate students, postgraduate students during the educational process, including labor and vocational training in educational institutions, organizations and enterprises in the territory of Ukraine, and extends to institutions of pre-school, general secondary, professional (vocational), extracurricular, specialized education, higher education and institutions of postgraduate education, regardless of ownership and subordination.

Prevention can only be achieved if evidence-based interventions are implemented effectively through systematic and organized approaches. Evidence has systematically been collated in a series of European and world reports on preventing injuries and violence. Sustained investments in safe environments (such as road and housing design) and products (like childproof lighters and packaging for medications), together with the use of legislation, regulation, enforcement and education for behaviour modification and skills development, has allowed many countries in the Region to continue to reduce injury-related deaths.

\section{The value of the S00-T98 category of diseases: Injury, poisoning} and certain other consequences of external causes in the structure

\section{of the general morbidity of the population of the Transcarpathian region}

The dynamics of general morbidity in Ukraine and Transcarpathian region for the period of 2014-2018 have already been considered. For a better understanding of the situation with injuries we have analyzed disease

\footnotetext{
${ }^{11}$ Pro zatverdzhennja Polozhennja pro porjadok rozsliduvannja neshhasnykh vypadkiv, shho stalysja iz zdobuvachamy osvity pid chas osvitnjogho procesu [Regulation on the Procedure of Investigation of Accidents that Occurred with the Students During the Educational Process]: Nakaz Ministerstva osvity i nauky Ukrajiny [Order of the Ministry of Education and Science of Ukraine] 2019, No. 659. Retrieved from: https://zakon.rada.gov.ua/laws/ show/z0612-19
} 
incidence in the category of diseases «Injury, poisoning and certain other consequences of external causes (S00-T98)».

The incidence rate (per 100,000 population) of the category "Injuries, Poisoning and Some Other Consequences of External Causes (S00-T98)" in Ukraine has been more stable in recent years, with changes occurring within 1\%: from 4023 in 2014 to 4010 in 2017 (Fig. 6).

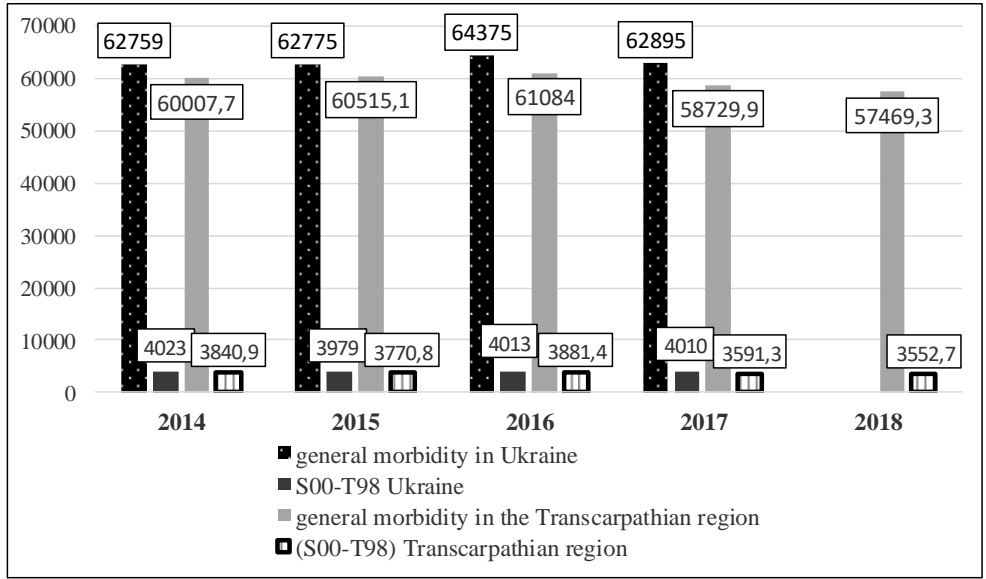

Fig. 6. Total morbidity and morbidity rates by disease of category S00-T98 in Ukraine and Transcarpathian region 2014-2018 (per 100 thousand population)

Although 62759 cases per 100000 population were first reported in Ukraine in 2014, the number of first-time cases identified by the category of «Injury, poisoning and certain other consequences of external causes (S00-T98)» was 6,4\% (4023 per 100 thousand people). It was found that in the Transcarpathian region the share of this category of $(3840,9$ per 100 thousand population) also made $6.4 \%$ in the structure of all first registered diseases in 2014 (60007,7 per 100 thousand population).

It was found that the highest incidence rate for the specified category S00-T98 is characteristic for the mountainous Rakhiv district $(5972,0$ per 100 thousand population), and the lowest for the district Irshava (2134,0 per 100 thousand population).

It was determined that in 2015 , with the total number of first-reported diseases in Ukraine 62775 per 100000 population, the share of the category «Injury, poisoning and certain other consequences of external causes (S00- 
T98)» was 6,3\% (3979 per 100000 people). In the structure of the overall incidence the share of diseases in the above category in the Transcarpathian region $(60515,1$ per 100 thousand population) was $6,2 \%$ and amounted to 3770,8 per 100 thousand population. A detailed analysis showed that in 2015 Rakhiv district also ranked the first in the incidence rate for category S00T98 (5821,2 per 100 thousand population), while in Irshava district the morbidity rate for that category increased 1,2 times (2617,5 per 100 thousand population) and the lowest rate was registered in Uzhhorod district (1255,4 per 100 thousand population).

The chart (Fig. 6) shows an increase in the overall incidence rate in Ukraine in 2016, which amounted to 2,5\% (up to 64375 per 100 thousand population). At the same time, the share of diseases of the category «Injury, poisoning and certain other consequences of external causes (S00-T98)» decreased to $6 . \%$ (4013 per 100 thousand population). In the Transcarpathian region, the overall incidence rate in 2016 also increased by $1 \%$ (61084,6 per 100 thousand population), but the share of the incidence by category S00-T98 (3881,4 per 100 thousand population), unlike in other regions of Ukraine, also increased to $6,4 \%$.

The analysis of morbidity rate made it possible to determine that in 2017 the total number of first registered diseases in Ukraine decreased to 62895 per 100 thousand population, but the share of diseases of the category «Injury, poisoning and certain other consequences of external causes (S00T98)» increased and amounted to 6,4\% (4010 per 100000 population). Instead, in 2017, the share of the above category in the Transcarpathian region decreased to $6.1 \%$ (3591,3 with the overall incidence in the region being 58729,9 per 100 thousand population).

The incidence rate of category S00-T98 (3552,7 per 100 thousand population) in the Transcarpathian region in 2018 decreased by $1,1 \%$, and its share in the structure of the total morbidity across the region ( 57469.3 per 100 thousand population) was $6,2 \%$.

A detailed analysis of the incidence rates of the Transcarpathian region by district revealed that during 2014-2018 the highest rate of morbidity of the category «Injury, poisoning and certain other consequences of external causes (S00-T98)» was recorded in Rakhiv district, except 2018, when the highest rate was registered in Tiachiv district (5460,0 per 100 thousand population).

Thus, the analysis of incidence rates of the category «Injuries, poisoning and some other consequences of external causes (S00-T98)» in the Transcarpathian region has shown a gradual decrease of 7,0\% over 5 years (2014-2018). But in the structure of all reported diseases in the region, the share of this category has remained almost unchanged and amounted to $6,1-6,4 \%$. 
It should be noted that trauma is one of the causes not only of morbidity and mortality, but also of disability of the population. This leads to permanent loss of working capacity of the adult population and, consequently, to production losses, as well as increases social payments, the cost of rehabilitation treatment and maintaining quality of life for the affected population.

Injuries as the cause of disability, ranked third after neoplasms and diseases of the musculoskeletal system in the structure of primary disability in the Transcarpathian region during 2014-2018.

During the period of five years (2014-2018), primary disability was recorded in 16858 persons of working age in the Transcarpathian region; in $10,9 \%$ cases the disability was caused by injuries.

Therefore, a separate analysis has been carried out of the information on primary disability status by adult disability groups in general and injuryrelated disability of the working age population in 2014-2018 based on the statistics of the Medical Social Expert Commission of the Transcarpathian region (Table 2).

Obviously, Group III (63-73\%) accounted for the majority of injuryrelated disabilities among disability groups for persons of working age. At the same time, $8,4 \%$ of all persons of working age who applied for disability status due to traumas have received Group I disability status in 5 years.

The analysis has shown that the share of the third disability group among persons of working age with primary injury-related disability within five years increased from $69,2 \%$ to $73,1 \%$. But the fact that the share of Group I decreased from $7,1 \%$ to $5,9 \%$ (Table 2) is positive.

In the structure of primary injury-related disability of persons of working age the share of Group II for the period of 2014-2018 took an average position and was $30,6 \%$ in 2017. In 2018 this figure dropped to $21,2 \%$.

All this highlights the importance of prevention of traumas and injury in general within the policy of preserving the working capacity of the region's population. 
Table 2

Primary injury-related disability of the population of the Transcarpathian region in 2014-2018

\begin{tabular}{|c|c|c|c|c|c|c|c|c|c|c|c|c|c|c|}
\hline \multirow{3}{*}{ Years } & \multicolumn{7}{|c|}{ Total population } & \multicolumn{7}{|c|}{ Working-age population } \\
\hline & \multirow{2}{*}{$\frac{\stackrel{\pi}{\frac{\pi}{6}}}{\stackrel{\dot{\theta}}{\sigma}}$} & \multicolumn{2}{|c|}{ 预 } & \multicolumn{2}{|c|}{ 总 } & \multicolumn{2}{|c|}{ 总是 } & \multirow{2}{*}{$\frac{\stackrel{\tilde{\pi}}{0}}{\dot{\theta}}$} & \multicolumn{2}{|c|}{ 莺 } & \multicolumn{2}{|c|}{ 总 } & \multicolumn{2}{|c|}{ 总是 } \\
\hline & & 完 & o & $\begin{array}{l}\dot{\sigma} \\
\frac{\sigma}{\sigma}\end{array}$ & $s^{\circ}$ & $\frac{\dot{\theta}}{\sigma}$ & $0^{\circ}$ & & 完 & $0^{\circ}$ & 完 & $\therefore$ & 完 & $\therefore$ \\
\hline ָั & $\tilde{y}$ & ले & a & 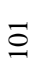 & ते & $\widetilde{\sim}$ & बें & \&̊+ & ते & $\vec{\therefore}$ & ஃ & $\ddot{\lambda}$ & $\vec{\sim}$ & ถู \\
\hline กิ่ & $\stackrel{\bigcirc}{\ni}$ & m & $\infty_{\infty}^{m}$ & $\infty$ & $\frac{n}{i}$ & $\stackrel{\infty}{\sim}$ & $\stackrel{1}{2}$ & $\infty$ & तิ & in & $\infty$ & $\stackrel{0}{\vec{N}}$ & 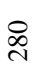 & $\hat{i}$ \\
\hline ํํำ & $\underset{n}{ \pm}$ & $\bar{\imath}$ & 2 & 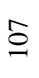 & $\begin{array}{l}0 \\
\text { Dे } \\
\text { in }\end{array}$ & $\stackrel{9}{\sim}$ & $\begin{array}{l}\text { r } \\
\text { t }\end{array}$ & 管 & $\beth$ & $\vec{f}$ & $\stackrel{\infty}{\sigma}$ & 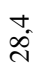 & તે & $\widehat{8}$ \\
\hline ลิ & $\bar{m}$ & $m$ & $a$ & gे & $\overrightarrow{\hat{\lambda}}$ & $\underset{\text { I }}{\text { S }}$ & है & in & ิ & $\tilde{n}$ & $\subseteq$ & : & & $\overline{8}$ \\
\hline 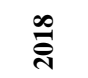 & ช̂? & $m$ & $\infty_{\infty}^{2}$ & $\infty$ & ¿ें & $\stackrel{\substack{i \\
i}}{i}$ & 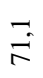 & $\stackrel{n}{m}$ & तิ & in & $\because$ & $\frac{N}{\pi}$ & $\stackrel{\infty}{\sim}$ & $\vec{\Re}$ \\
\hline 吾 & 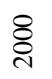 & $\stackrel{\infty}{\circ}$ & ${ }_{\infty}^{+}$ & $\begin{array}{l}\infty \\
\infty \\
+\end{array}$ & $\dot{d}$ & $\stackrel{7}{2}$ & $\frac{2}{8}$ & ले & $\stackrel{\infty}{=}$ & के & भे & & $\stackrel{\mathbb{I}}{\stackrel{I}{2}}$ & ถู \\
\hline
\end{tabular}

\section{CONCLUSIONS}

Traumatism has significant medical and social importance for the state and each of its regions, since its spread affects the mortality rate, causes significant economic losses in production, leads to increased costs of medical care, rehabilitation treatment and maintaining the quality of life of individuals.

Systematic analysis shows that over the last five years (2014-2018) the incidence rate (per 100000 population) of the category of diseases «Injury, poisoning and certain other consequences of external causes (S00-T98)» in Ukraine has decreased by 1\%: from 4023 in 2014 to 4010 in 2017. In the Transcarpathian region the incidence rate for the specified category has decreased gradually by $7 \%$ during 2014-2018: from 3840,9 to 3552,7 per 100 thousand population. However, in the structure of all reported diseases 
in the region, the share of S00-T98 diseases has remained almost unchanged, accounting for $6,1-6,4 \%$.

It has been found that the overall rate of injuries in the Transcarpathian region has decreased by $7,5 \%$ over 5 years since 2014 . This period has been characterized by an increase in the share of domestic injuries, a decrease in street and minor fluctuations in road, sports and occupational injuries. In general, the rates of all types of injuries have reduced across the Transcarpathian region.

The analysis of the structure of primary disability in the Transcarpathian region during 2014-2018 has shown that injuries as a cause of disability ranked third after neoplasms and diseases of the musculoskeletal system.

Despite some positive dynamics, the traumatism situation requires consolidated efforts by society towards the prevention of the spread of trauma through cross-sectoral interaction at the state and regional levels. The specific features of each region should be taken into account in developing injury prevention and trauma care measures.

\section{SUMMARY}

Traumatism has significant medical and social importance for the state and each of its regions, since its spread affects the mortality rate, causes significant economic losses in production, leads to increased costs of medical care, rehabilitation treatment and maintaining the quality of life of individuals with disabilities.

Special attention has been given to the westernmost region of Ukraine, the Transcarpathian region, which is characterized by certain features: the predominance of rural population (63\%), borderline placement (with 4 other countries), a large number of villages with the status of mountain settlements, recurrent natural disasters such as floods, massive migration to other regions of Ukraine and abroad, and so on. In order to plan injury prevention measures in the Transcarpathian region, the dynamics and state of the spread of various types of injuries in the region in 2014-2018 have been analyzed. Systematic analysis has shown that the overall rates of injuries in the Transcarpathian region has decreased by 7,5\% over 5 years since 2014. This period has been characterized by an increase in the share of domestic injuries, a decrease in street and minor fluctuations in road, sports and occupational injuries. In general, there is a tendency for all types of injuries in the Transcarpathian region to decrease.

Despite some positive dynamics, the traumatism situation requires consolidated efforts by society towards the prevention of the spread of trauma through cross-sectoral interaction at the state and regional levels. The 
specific features of each region should be taken into account in developing injury prevention and trauma care measures.

\section{REFERENCES}

1. Sethi D, Mitis F, Racioppi F. (2010). Preventing injuries in Europe: from international collaboration to local implementation. Copenhagen: WHO Regional Office for Europe. Retrieved from: http://www.euro.who.int/en/publications/ abstracts/preventing-injuries-ineurope-from-international-collaboration-to-localimplementation.

2. Aldridge E, Sethi D. Yon Y. (2017). Injuries: a call for public health action in Europe. Copenhagen: WHO Regional Office for Europe. Retrieved from: http://www.euro.who.int/_data/assets/pdf_file/0018/348102/ WH08_IJ_complete-web-version.pdf?ua=1

3. Derzhavna sluzhba statystyky Ukrainy (2017) Zaklady okhorony zdorov'ja ta zakhvorjuvanistj naselennja Ukrajiny u 2016 roci [Healthcare institutions and the incidence of the population of Ukraine in 2016], Kyiv. Retrieved from: http://www.ukrstat.gov.ua/druk/publicat/kat_u/2016/bl/06/bl_zoz_15xl.zip

4. Derzhavna sluzhba statystyky Ukrainy (2018) Zaklady okhorony zdorov'ja ta zakhvorjuvanistj naselennja Ukrajiny u 2017 roci [Healthcare institutions and the incidence of the population of Ukraine in 2017], Kyiv. Retrieved from: http://www.ukrstat.gov.ua/druk/publicat/kat_u/2018/ zb/06/zb_zoz_17.pdf

5. Dmytrjuk S. P., Ghodjajev S. Gh. (2017). Osnovni prychyny ta metody analizu pokaznykiv vyrobnychogho travmatyzmu [Principal reasons and methods of analysis of indexes of production traumatism of]. Budivnyctvo, materialoznavstvo, mashynobuduvannja. Z Zb. nauk. pracj [Construction, materials science, mechanical engineering], vol. 101, pp.94-99.

6. Lazebnyk Ju. O. (2018). Proghramno-metodologhichni zasady udoskonalennja nacionaljnoji systemy sposterezhennja zi statystyky travmatyzmu [Program-methodological Principles of Improvement of the National System of Statistical Observation of Traumatism]. Statistics of the Ukraine, no. 3, pp. 49-58.

7. Barannyk L. B. (2019) Zdorov'ja naselennja jak indykator rozvytku socialjnogho kapitalu v Ukrajini [Public health as an indicator of the social capital development in Ukraine]. Scientific Notes of Ostroh Academy National University, «Economics» series, no. 12, pp. 64-69. Retrieved from: http://nbuv.gov.ua/UJRN/Nznuoa_2019_12_12.

8. Pro zatverdzhennja Nacionaljnogho planu zakhodiv shhodo neinfekcijnykh zakhvorjuvanj dlja dosjaghnennja ghlobaljnykh cilej stalogho 
rozvytku [National Action Plan on the Prevention of Noncommunicable Diseases for Achieving Global Sustainable Development Goals]: Rozporjadzhennja Kabinetu Ministriv Ukrajiny [Cabinet of Ministers of Ukraine] 2018, No. 530-p. Retrieved from: https://www.kmu.gov.ua/ua/ npas/pro-zatverdzhennya-nacionalnogo-planu-zahodiv-shchodoneinfekcijnih-zahvoryuvan-dlya-dosyagnennya-globalnih-cilej-stalogorozvitku

9. State Service of Ukraine on Labor (2019) Statystychni dani vyrobnychogho travmatyzmu z pochatku roku [Statistical data occupational injuries YTD]. Retrieved from: http://dsp.gov.ua/statystychni-danivyrobnychoho-travma-2/

10. Mitina NB., Babenko O.Ju., Vorobjova L.O., Malynovsjka N.V. (2018) Doslidzhennja stanu travmatyzmu ta rivnja profesijnoji zakhvorjuvanosti na promyslovykh ob'jektakh Ukrajiny [Study of the state of traumatic and professional disease level on industrial objects of Ukraine]. Budivnyctvo, materialoznavstvo, mashynobuduvannja. Z $b$. nauk. pracj [Construction, materials science, mechanical engineering], vol. 105, pp.139-147.

11. Pro zatverdzhennja Polozhennja pro porjadok rozsliduvannja neshhasnykh vypadkiv, shho stalysja iz zdobuvachamy osvity pid chas osvitnjogho procesu [Regulation on the Procedure of Investigation of Accidents that Occurred with the Students During the Educational Process]: Nakaz Ministerstva osvity i nauky Ukrajiny [Order of the Ministry of Education and Science of Ukraine] 2019, No. 659. Retrieved from: https://zakon.rada.gov.ua/laws/show/z0612-19

\section{Information about the author:} Brych V. V., orcid.org/0000-0003-3741-6002 Associate Professor at the Department of Health Sciences Uzhhorod National University 29, Mytna str., 88000, Uzhhorod, Ukraine 